\title{
Fibroblast activation protein $\alpha$ in tumor microenvironment: Recent progression and implications (Review)
}

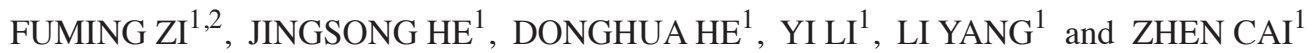 \\ ${ }^{1}$ Department of Hematology, Bone Marrow Transplantation Center, The First Affiliated Hospital, School of Medicine, \\ Zhejiang University, Hangzhou, Zhejiang 310003; ${ }^{2}$ Department of Hematology, The Second Affiliated Hospital, \\ School of Medicine, Nanchang University, Nanchang, Jiangxi 330006, P.R. China
}

Received January 18, 2014; Accepted August 14, 2014

DOI: $10.3892 / \mathrm{mmr} .2015 .3197$

\begin{abstract}
Accumulated evidence has demonstrated that the microenvironment of a given tumor is important in determining its drug resistance, tumorigenesis, progression and metastasis. These microenvironments, like tumor cells, are vital targets for cancer therapy. The cross-talk between tumor cells and cancer-associated fibroblasts (CAFs, alternatively termed activated fibroblasts) is crucial in regulating the drug resistance, tumorigenesis, neoplastic progression, angiogenesis, invasion and metastasis of a tumor. Fibroblast activation protein $\alpha(\mathrm{FAP} \alpha)$ is a transmembrane serine protease and is highly expressed on CAFs present in $>90 \%$ of human epithelial neoplasms. FAP $\alpha$ activity, alongside that of gelatinase and type I collagenase, has become increasingly important in cancer therapy due to its effectiveness in modulating tumor behavior. In this review, recent progression in the knowledge of the role of FAP $\alpha$ in tumor microenvironments is discussed.
\end{abstract}

\section{Contents}

1. Introduction

2. The discovery of FAP $\alpha$

3. The structure of FAP $\alpha$

4. Expression of FAP $\alpha$ in the tumor microenvironment and in benign diseases

5. Factors driving the expression of FAP $\alpha$

6. Tumorigenic and anti-tumor functions of FAP $\alpha$

7. FAP $\alpha$ in tissue remodeling

8. FAP $\alpha$ and its association with clinical prognosis

9. FAP $\alpha$ substrate cleavage

Correspondence to: Professor Zhen Cai, Department of Hematology, Bone Marrow Transplantation Center, The First Affiliated Hospital, School of Medicine, Zhejiang University, 79 Qingchun Road, Hangzhou, Zhejiang 310003, P.R. China E-mail: caizhen1@sina.com

Key words: cancer-associated fibroblasts, fibroblast activation protein $\alpha$, tumor microenvironment

\section{Clinical applications of FAP $\alpha$ targeting}

11. Conclusion

\section{Introduction}

Cancer tissue is a sophisticated construct of both malignant tumor cells and nonmalignant host stromal cells. In 1889, Paget (1) proposed a novel concept, the 'seed and soil' hypothesis, postulating that the congenial microenvironment (the 'soil') is prerequisite for the progression of tumor cells (the 'seeds'). Tumor cells are disseminated throughout the body via the blood stream, but only in congenial 'soil' can metastases develop. In the past, cancer research primarily focused on neoplastic cells. This led to a rapid progression of knowledge pertaining to the genetic and epigenetic changes they undergo and elucidation of their signaling pathways in tumor cells $(2,3)$. Despite the advancement of knowledge in the malignant transformation of tumor cells, existing therapies remain relatively ineffective for most types of cancer. Hertenstein et al (2), SalaTorra et al (5) and Xiao et al (6), respectively, reported that leukemia patients suffered from donor cell leukemia (DCL) following allogeneic hematopoietic stem cell transplantation (allo-HSCT). In Xiao et al's study (6), the patient in question as well as his donor-sister had the CCAAT enhancer binding protein $\alpha$ genetic abnormality, however, leukemia did not manifest in the patient's sister. Other studies have also demonstrated that cells containing abnormal genetic changes only lead to tumor formation in a congenial microenvironment (7-10).

The results of the aforementioned studies revealed that genetic abnormality in tumor cells alone is not sufficient to produce cancer cells with malignant characteristics. The tumor microenvironment may be a necessity in the inception of malignant tumors and is increasingly being recognized to have a vital role in the progression of solid tumors and hematological malignancies (11-14). Cancer-associated fibroblasts (CAFs) are the most ubiquitous element of tumor stroma and are found in numerous types of cancer, including breast (15,16), NSCLC (17), colorectal (18-20), liver (21) and prostate cancer (22). The exact origin and specific markers of CAFs remain to be elucidated. Contemporary knowledge suggests that CAFs may be derived from: $i$ ) Local resident 


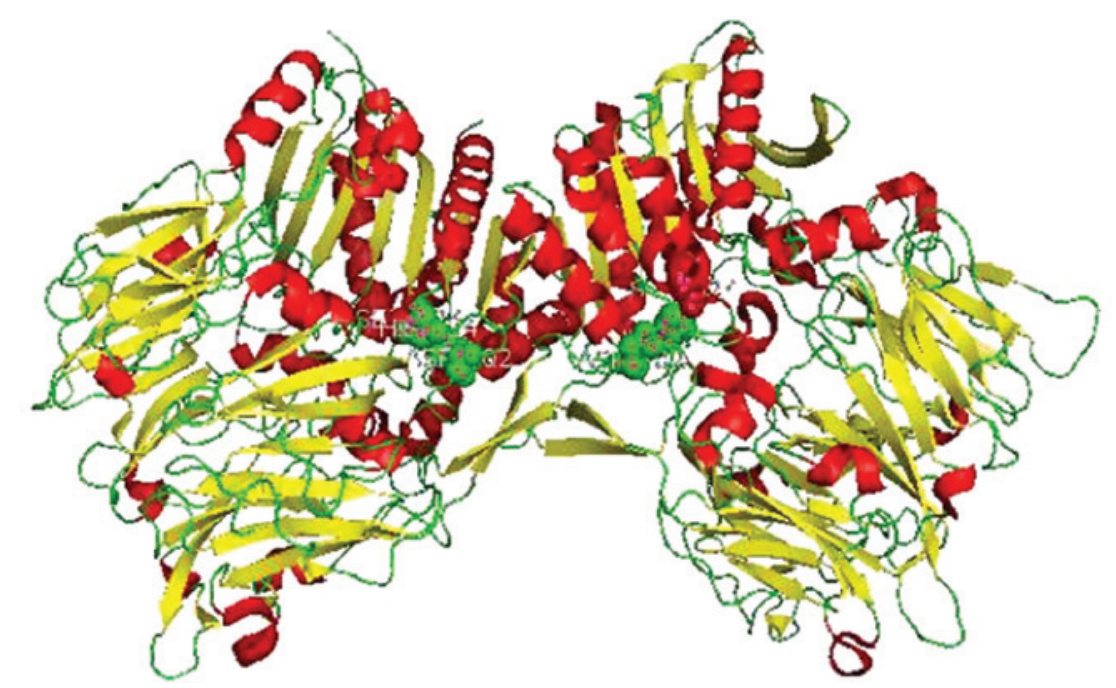

Figure 1. Ribbon diagram demonstrating the architecture of the fibroblast activation protein $\alpha$ dimer. Active amino acid residues Ser624, Asp702 and His734 are represented in sphere representations. The figure was generated using PyMOL (PDB ID 1Z68). Red, helix; yellow, $\beta$-sheet; green, loop and others.

fibroblasts that undergo education by tumor cell-secreted cytokines; ii) bone marrow-derived mesenchymal stem cells (BMMSCs); iii) cancer cells undergoing epithelial-mesenchymal transition (EMT); $i v$ ) endothelial cells undergoing endothelial-to-mesenchymal transition (EndoMT); and v) other mechanisms (23-25). Fibroblast activation protein $\alpha$ (FAP $\alpha$ ) is an important surface marker of CAFs. Aggregated data revealed that the elimination of FAP $\alpha$ led to stunted tumor growth and progression and stimulated the immune system to enhance the effects of tumor vaccination (26-30).

In the present review, the current knowledge regarding the role of FAP $\alpha$ in the interaction between cancer cells and the tumor microenvironment, as well as its biological and therapeutic implications, were summarized.

\section{The discovery of FAP $\alpha$}

In 1986 and 1988, using the monoclonal antibody (mAb) F19, Rettig et al $(31,32)$ identified a surface protein-F19 on the reactive stromal fibroblasts of epithelial cancers, most soft tissue sarcomas and granulation tissue of wound healing and certain fetal mesenchymal tissues, including fibroblasts in the dermis, perichondrium, renal capsule and peritoneum. Conversely, it was found that the stroma of benign epithelial tumors, normal and malignant epithelial cells, malignant hematopoietic cells, as well as normal stromal fibroblasts of the fetal kidney, colon, lung and cartilage and skeletal muscle were F19-negative (31). Subsequently, this mAb F19-identified protein was named fibroblast activation protein (FAP) (33-36). The human FAP, a cell surface protein, is comprised of Mr 95,000 (p95, FAP $\alpha$ ) and $\mathrm{Mr} 105,000$ (p105, FAP $\beta$ ) subunits, which are conjugated by noncovalent, non-disulfide bonds. FAP $\beta$ is identical to T cell activation protein CD26 (also known as dipeptidyl peptidase 4, DPP 4) $(35,37)$. Immunoblot experiments revealed that FAP $\alpha$, but not FAP $\beta$, carries the epitope defined by $\mathrm{mAb}$ F19 (33) and the F19 surface antigen was renamed as FAP $\alpha$. In 1990, Aoyama and Chen (38) identified a dimeric $170 \mathrm{kDa}$ membrane-bound gelatinase in the invadopodia of the aggressive malignant human melanoma cell line LOX. In 1994, this dimeric $170 \mathrm{kDa}$ gelatinase was given the name 'seprase' (39). Subsequent cloning and sequence analysis of FAP $\alpha$ and seprase indicated that they were the identical transmembrane protease $(40,41)$. In the present review, the term FAP $\alpha$ was used to denote this serine protease.

\section{The structure of FAP $\alpha$}

FAP $\alpha$, expressed in activated stromal fibroblasts and remodeling tissue, is a type II cell-surface-bound transmembrane glycoprotein with $\mathrm{Mr} 95,000$. It consists of 760 amino acids, most of which possess a hydrolytic area exposed laterally of the plasmalemma. 20 amino acids are anchored in the plasma membrane, and 6 amino acids are located in the cytoplasm (42). The conserved catalytic triad of FAP $\alpha$ is comprised of serine (S624), aspartate (D702) and histidine (H734) $(42,43)$ (Fig. 1). FAP $\alpha$ is a member of the peptidase $\mathrm{S} 9 \mathrm{~b}$ family, a serine prolyl oligopeptidase subfamily, with post-prolyl peptidase activities able to cleave proteins and peptides following proline residues at the penultimate and P1 positions (44). In addition to FAP $\alpha$ $(E C=3.4 .21)$, this $S 9 b$ serine peptidase family includes dipeptidyl peptidase 4 (DPP4, also termed CD26, which is identical to FAP $\beta, E C=3.4 .14 .5$ ), dipeptidyl aminopeptidase-like protein 6 (also named DPPX or DPP6), DPP8 (EC=3.4.14.5), DPP9 (EC $=3.4 .14 .5)$ and DPP10, and has been implicated in diabetes, cancer and inflammatory diseases (45-47) (additional information is available at: http://www.uniprot.org; http://enzyme.expasy.org). FAP $\alpha$ shares $48 \%$ amino acid sequence identity with DPP4 (35). FAP $\alpha$ and DPP4 are able to form homodimer FAP $\alpha / \mathrm{FAP} \alpha$ or heterodimer FAP $\alpha / \mathrm{DPP} 4$ complexes to execute functions. The FAP $\alpha$ monomer is inactive, therefore dimerization is prerequisite for its catalytic function $(43,48,49)$. FAP $\alpha$ and DPP4 are encoded by genes on human chromosomes 2q23 and 2q24.3, respectively $(41,50)$. DPP8 and DPP9 are localized to chromosomes 15q22 and $19 \mathrm{p} 13.3$, respectively (51). DPP6 is encoded by a gene on human chromosome $7(41,52)$ and DPP10 is encoded by a gene localized to chromosome 2 (2q12.3-2q14.2) (47). Murine 
Table I. Tissue distribution of FAP $\alpha$.

\begin{tabular}{|c|c|c|}
\hline Antigen & Antigen-expressing cell types or tissues & References \\
\hline F19 & $\begin{array}{l}\text { Cultured fibroblasts; granulation tissue; pancreatic islet (A) cells; fetal } \\
\text { mesenchymal tissues (fibroblasts in the dermis, renal capsule, perichondrium, } \\
\text { peritoneum); fibrosarcoma; malignant fibrous histiocytoma; leiomyosarcoma; } \\
\text { osteosarcoma; hondrosarcoma; liposarcoma; synovial sarcoma; schwannoma, } \\
\text { partial melanoma cell lines. }\end{array}$ & $(32,33)$ \\
\hline Seprase/FAP $\alpha$ & $\begin{array}{l}\text { Melanoma cell line, infiltrating ductal carcinomas, pancreatic ductal } \\
\text { adenocarcinoma and pancreatic cancer cell lines (SW1990, Miapaca-2, AsPC-1 } \\
\text { and BxPC-3), cancer cells of colorectum, stomach and uterine cervix; glioma } \\
\text { cells. }\end{array}$ & $(38,55,64-68)$ \\
\hline F19 & $\begin{array}{l}\text { Reactive mesenchyme of epithelial and nonepithelial tumors (colorectal, breast, } \\
\text { ovarian and bladder tumors; lung cancer; mesothelioma; gastric, pancreatic, } \\
\text { endometrial and neuroendocrine cancers; melanoma;lymphoma). }\end{array}$ & $(36,54)$ \\
\hline F19 & Hepatic stellate cells of cirrhotic liver. & $(56)$ \\
\hline $\mathrm{FAP} \alpha$ & $\begin{array}{l}\text { Bone marrow-derived mesenchymal stem cells, osteoclasts, vascular endothelial } \\
\text { cells, adipocytes. }\end{array}$ & $(61,62)$ \\
\hline $\mathrm{FAP} \alpha$ & Fibroblast foci and fibrotic interstitium of idiopathic pulmonary fibrosis. & $(57)$ \\
\hline F19 & Fibroblast-like synoviocytes of rheumatoid arthritis and osteoarthritis. & $(58)$ \\
\hline $\mathrm{FAP} \alpha$ & Submucosa of Crohn's disease strictures; atherosclerotic plaques. & $(59,60)$ \\
\hline
\end{tabular}

FAP $\alpha$, fibroblast activation protein $\alpha$.

FAP $\alpha$ shares $89 \%$ amino-acid-sequence identity with human FAP $\alpha$ (37). A promoter element of FAP $\alpha$, early growth response 1 (EGR1), has been described (53).

\section{Expression of FAP $\alpha$ in the tumor microenvironment and in benign diseases}

Approximately $90 \%$ of reactive stromal fibroblasts of epithelial tumors, but not malignant tumor cells, overexpress FAP $\alpha(31,54)$. Immunohistochemical analysis using formalin-fixed and paraffin-embedded sections disclosed expression of FAP $\alpha$ in infiltrating ductal carcinomas (IDC) (55). The data indicated that the majority of stromal fibroblasts of epithelial tumors and certain malignant tumor cells are characterized by an overexpression of FAP $\alpha$ (Table I).

Further to overexpression in the cells and tissues mentioned above and summarized in Table I, FAP $\alpha$ is also expressed in certain benign diseases and normal tissues.

In 1999, Levy et al (56) examined 17 cirrhotic and eight normal liver samples by immunohistochemistry and RT-PCR. The results indicated that FAP $\alpha$ was mainly expressed in the hepatic stellate cells or perisinusoidal cells in periseptal regions of cirrhotic liver samples. Acharya et al (57) found that FAP $\alpha$ was expressed on fibroblast foci and in the fibrotic interstitium of patients with idiopathic pulmonary fibrosis (IPF), but was not expressed in normal or centriacinar emphysemal human lung tissue. Bauer et al (58) examined the FAP $\alpha$-expression of fibroblast-like synoviocytes (FLSs) from patients with rheumatoid arthritis (RA) and osteoarthritis (OA) and found that FAP $\alpha$ expression was higher in FLSs from RA patients than in those from OA patients. Immunohistochemical analysis indicated that FAP $\alpha$ was forcefully expressed in the submucosa of Crohn's disease (CD) strictures, but not in the submucosa of nonstrictured areas, ulcer (UC) submucosa or normal submucosa (59). FAP $\alpha$ expression was also observed in coronary atheromata, particularly in thin-cap atheromatas (60).

In normal tissue, cultured fibroblasts, but not resting fibroblasts, have a strong expression of FAP $\alpha$. The cultural conditions may mimic the 'wounds that do not heal' state. Another important normal cell type that expresses FAP $\alpha$ is bone marrow mesenchymal stem cells (BMMSCs) $(61,62)$. In the light of present knowledge, it is difficult to make a clear distinction between BMMSCs and fibroblasts. It appears that MSCs and fibroblasts share properties beyond those previously understood and that MSCs may in fact be fibroblasts' new 'clothes' (63). Therefore, BMMSCs may be regarded as cultured fibroblasts. Table I lists FAP $\alpha$-expressing tissues.

\section{Factors driving the expression of FAP $\alpha$}

FAP $\alpha$ expression may be elevated under the influence of an altered tumor microenvironment or inflammation. In vitro FAP $\alpha$ expression was observed in fibroblasts and melanocytes cultured in fibroblast growth factor (FGF) and phorbol ester (33). Treatment of FB20 cells with human transforming growth factor- $\beta 1$ (TGF- $\beta 1), 12$ - $o$-tetradecanoyl phorbol-13-acetate (TPA), retinol or retinoic acid for 24-48 h increased FAP $\alpha$ expression in the cells (34). FAP $\alpha$ expression in CD strictured myofibroblasts under the stimulation of $10 \mathrm{ng} / \mathrm{ml}$ tumor necrosis factor $\alpha$ (TNF- $\alpha)$ or TGF- $\beta 1$ for $48 \mathrm{~h}$ was significantly increased (59). TNF- $\alpha$, produced by 


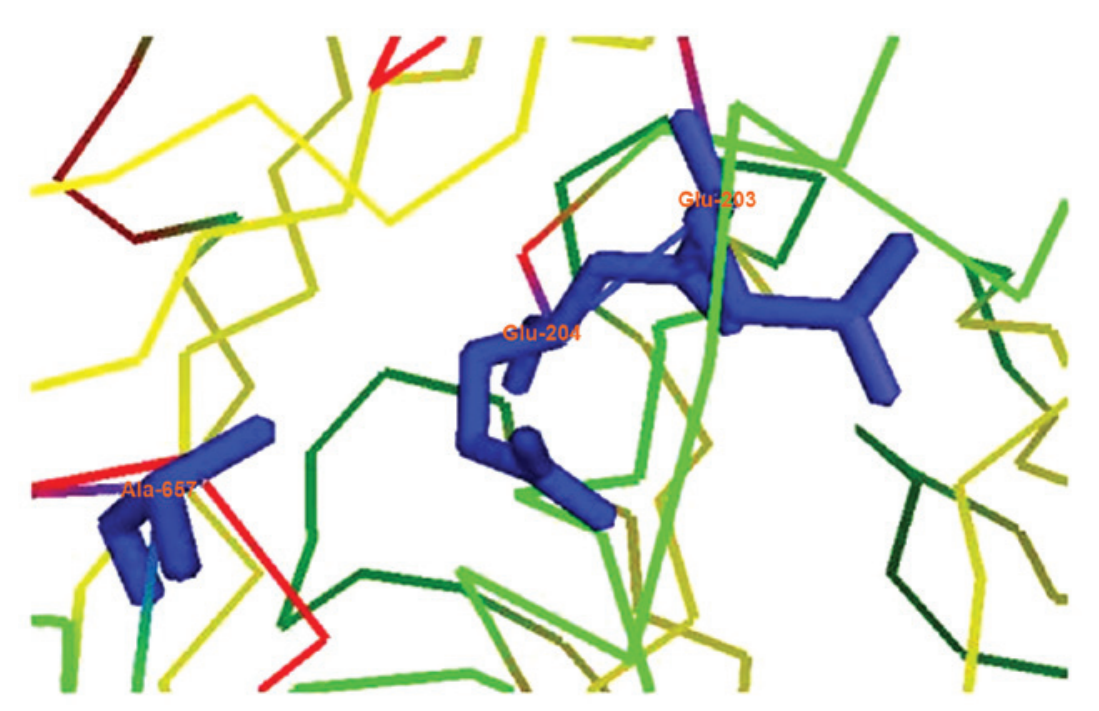

Figure 2. Glu motif of fibroblast activation protein $\alpha$ (Glu203-Glu204 and Ala657) with stick-representations. The figure was generated using PyMOL.

macrophages, was also able to induce FAP $\alpha$ expression in cultured human aortic smooth muscle cells (60). Further to the cytokines and chemical substances which induce FAP $\alpha$ expression, physical stimulants, including ultraviolet radiation, also induce upregulation of FAP $\alpha$ expression in fibroblasts, melanocytes and primary melanoma cells to facilitate invasion and migration of the cells (69).

\section{Tumorigenic and anti-tumor functions of FAP $\alpha$}

HEK293 cells and MDA-MB-231 human mammary adenocarcinoma cells were transfected with FAP $\alpha$ cDNA to constitutively express FAP $\alpha$, and subsequently xenografted into SCID mice. The transfected cells were more likely to develop subcutaneous tumors and demonstrated enhanced tumor growth $(70,71)$ as well as increased microvessel density (71), compared with mock-transfected cells. Antibodies that neutralized FAP $\alpha$ attenuated the tumor growth rate (70). The human breast cancer cell lines MDA-MB-435 and MDA-MB-436, stably transfected with anti-sense oligonucleotides of FAP $\alpha$, demonstrated slower proliferation than their FAP $\alpha$-expressing counterparts in serum-free medium but not in serum-containing medium, indicating that breast cancer cells with high FAP $\alpha$ expression levels may be independent from exogenous serum factors for growth (72). Planting FAP $\alpha$ silenced SKOV3 cells in a xenograft mouse model resulted in significantly decreased tumor growth (73). This is consistent with the observation that the elimination of FAP $\alpha$-expressing cells led to stunted tumor growth and enhanced anti-tumor immune response in a mouse model (30). Radioimmunotherapy with novel internalizing antibody ESC11 delayed growth of established tumors and extended survival of mice (74). Mutation at the site of $\mathrm{Ser}^{624} \rightarrow \mathrm{Ala}^{624}$ of FAP $\alpha$ resulted in $\sim 100,000$-fold decrease in DPP activity and attenuated tumor growth when HEK293 cells transfected with enzymatic mutant (S624A) FAP $\alpha$ were inoculated subcutaneously into a CB17SCID mouse (27). FAP $\alpha$ was upregulated in bone marrow mesenchymal stem cells and osteoclasts when co-cultured with myeloma cells and supported myeloma cell survival (61).
Inhibition of FAP $\alpha$ with PT-100 (Val-boro-Pro) influenced the expression of adhesion molecules in osteoclasts and reduced myeloma growth and bone disease (75). In a mouse model, inhibition of FAP $\alpha$ with PT-100 resulted in an antitumor effect implicating tumor-specific cytotoxic T lymphocytes, protection of immunological memory, augmented antitumor activity of antibody-increasing cytokines [interleukin (IL)-1, IL-6, interferon, granulocyte-colony stimulating factor] and chemokines (76). Taken together, these studies indicated that FAP $\alpha$ is a tumor promoter.

Tumor immunotherapy is important for eradicating tumors with minimal residual disease. Tumor-associated antigens are able to spontaneously elicit a CD8(+) T-cell response (77). However, the results of therapeutic vaccination with such antigens in inhibiting tumor growth have been relatively ineffective. This may be associated with the immunosuppressive effect of the stromal cells surrounding tumors. A study demonstrated that depleting FAP $\alpha$-expressing cells in a transgenic mouse elicited antitumor immunity, and thus indicated that FAP $\alpha$-expressing cells are an immune-suppressive component of the tumor microenvironment (30). This result is in accordance with evidence that an oral DNA vaccine targeting FAP $\alpha$ is able to suppress primary breast carcinoma growth and metastasis (28). This process may be associated with a shift in the immune microenvironment from expression of $T$ helper cells $\left(T_{h}\right) 2$ to $T_{h} 1$ (78).

While numerous studies demonstrated that FAP $\alpha$ was a tumor suppressor, in 1993, Rettig et al (33) observed that FAP $\alpha$ expression in melanocytes was downregulated once they transformed into malignant cells and acquired tumorigenic potential. Analysis of human skin lesions, detected by immunohistochemical analysis, indicated that FAP $\alpha$ was expressed in only a fraction of melanocytic nevi and expression was scarce in both primary and metastatic melanoma lesions (79). By hybridizing normal fibroblasts with tumorigenic and nontumorigenic HeLa cells, Tsujimoto et al (80) identified FAP $\alpha$ as a potential inhibitor of tumorigenesis. All these observations were consistent with Brown et al's (81) discovery that Xenopus laevis demonstrate a marked expression of FAP $\alpha$ whilst reabsorbing tadpole tails 


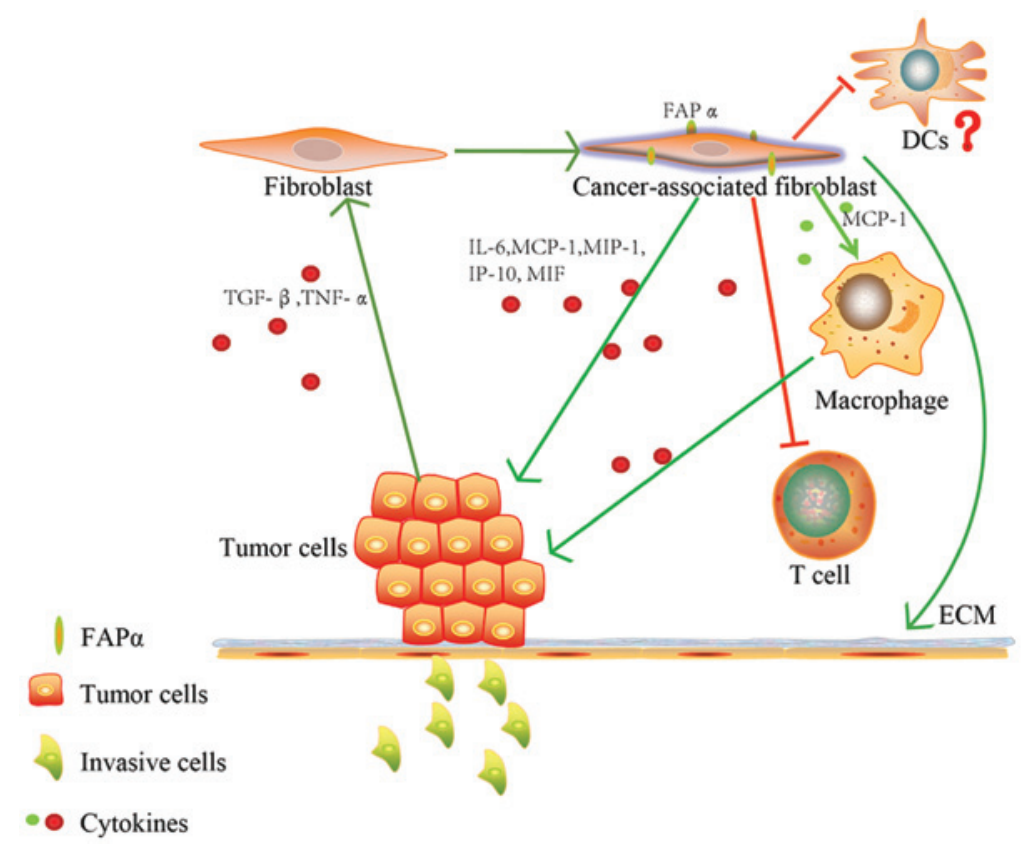

Figure 3. Intricate interaction of tumor cells with FAP $\alpha$ in tumor microenvironment. Tumor cells and its secreted cytokines (including TGF- $\beta$, TNF- $\alpha$ and SDF-1) educate resting fibroblasts to become activated fibroblasts with higher expression of FAP $\alpha$. FAP $\alpha$, through direct or indirect contact (cytokines, including IL-6, MCP-1, MIP and IL-1) supports tumor-cell survival. FAP $\alpha$ remodels the ECM and increases the invasive capability and metastasis of tumor cells. FAP $\alpha$ promotes cancer-associated fibroblasts to secrete MCP-1, mediating macrophage chemoattraction to the tumor microenvironment. The immune function of T cells was suppressed by FAP $\alpha$, leading to immune anergy. FAP $\alpha$, fibroblast activation protein alpha; TGF- $\beta$, transforming growth factor beta; TNF- $\alpha$, tumor necrosis factor alpha; SDF-1, stromal cell-derived factor 1; IL, interleukin; MCP-1, monocyte chemoattractant protein-1; MIP, macrophage inflammatory protein 1; ECM, extracellular matrix; DCs, dendritic cells.

during amphibian metamorphosis. This indicated that FAP $\alpha$ was a pro-apoptotic factor involved in tissue remodeling. FAP $\alpha$ also enhanced apoptosis in the mouse B16 melanoma cell line independent of DPP4 and its enzymatic activity (82).

Recently, a study using transgenic mice revealed that $\mathrm{FAP} \alpha(+)$ cells may have important functions in maintaining normal muscle mass and hematopoiesis, and their expression in normal tissues may have an important role in the paraneoplastic syndromes of cachexia and anemia (83). Niedermeyer et al (84) found that, in vivo, homozygous FAP $\alpha$-deficient mice generated from homologous recombination in the embryonic stem cell line R1 were fertile and exhibited no overt developmental defects or general changes in cancer susceptibility. Therefore, the function of FAP $\alpha$ may vary between tumor contexts and require further study.

FAP $\alpha$ not only has an important role in regulating tumor behavior, but also influences CAF behavior. Silencing FAP $\alpha$ with short interfering RNA transfected using a lentiviral vector inhibited growth and resulted in cell cycle arrest at the $\mathrm{G}_{2}$ and $\mathrm{S}$ phases of cancer-associated fibroblasts in vitro (73).

\section{FAP $\alpha$ in tissue remodeling}

Tissue remodeling is important in development, wound healing, chronic inflammation, fibrosis and cancer. It is understood that an active stroma is essential for cancer cell invasion and metastasis (85). Invasion and metastasis of malignant cancer cells requires the degradation of the extracellular matrix (ECM). FAP $\alpha$ displays DPP and gelatinolytic activity as proved by gelatin zymography and can cleave native ECM proteins, including collagen I, collagen IV, fibronectin, laminin and gelatin (38-40,49,86). These enzyme activities depend on the mutation at position $\mathrm{Ser}^{624}$, which abrogates the DPP and collagenase activity of FAP $\alpha$ (49). These enzymatic activities indicate that $\mathrm{FAP} \alpha$ may have a prominent role in tumor invasion, metastasis and angiogenesis (86-88). Clinical observation revealed that the overexpression of FAP $\alpha$ by ductal carcinomas is congruent with the invasion and metastasis of infiltrating ductal carcinomas (IDC) of the breast (55). Using an in vivo-like three-dimensional matrix system, Lee et al (89) observed that FAP $\alpha$ remodeled the ECM and increased the invasive capability and metastasis of pancreatic tumors, mediated by $\beta 1$-integrin/focal adhesion kinase.

In 1999, Levy et al (56) examined the biochemical activities of FAP $\alpha$ and found that FAP $\alpha$ exhibited gelatinase- and DPP-like activities. They concluded that FAP $\alpha$ may contribute to the hepatic stellate cell-induced ECM changes associated with cirrhosis. Wang et al (90) also found that human embryonic kidney 293T cells and hepatic stellate cell (HSC) line LX-2 overexpressing FAP $\alpha$ increased staurosporine streptomyces-induced cell apoptosis. However, FAP $\alpha$-overexpression in these cells had contrasting effects on cell adhesion and migration, causing a reduction in that of kidney 293T cells and an increase in that of LX-2 cells. These nonenzymatic functions of FAP $\alpha$ may function in liver-tissue remodeling through enhancement of HSC cell adhesion, migration and apoptosis (90).

In addition to DPP activity, FAP $\alpha$ also demonstrates endopeptidase activity due to the presence of $\mathrm{Ala}^{657}$, which leads to decreased acidity in the active site of the FAP $\alpha$ Glu motif (E203E204; Fig. 2) (43,49). Fig. 3 summarizes the intricate interaction of tumor cells with FAP $\alpha$ in the tumor microenvironment. 


\section{FAP $\alpha$ and its association with clinical prognosis}

The role of FAP $\alpha$ is controversial as it remains associated with tumor promotion and inhibition; therefore, the clinical significance of FAP $\alpha$ expression requires further study. Using immunohistochemical analysis, Wikberg et al (90) found that FAP $\alpha$ was expressed by stromal fibroblasts in $85-90 \%$ of colorectal cancers and that increased FAP $\alpha$ expression in the cancer center, but not in the outlying regions, was associated with microsatellite instability, high $\mathrm{CpG}$ island methylator phenotype and poor prognosis. FAP $\alpha$ expression in pancreatic adenocarcinoma is associated with desmoplasia and a worse prognosis $(64,92)$. Henry et al $(93)$ reported that patients with colon cancer who had high levels of stromal FAP $\alpha$ expression were more likely to demonstrate progression of disease, latent occurrence or recurrence of metastases and poor prognosis. FAP $\alpha$ is also involved in tumor re-growth and recurrence and high FAP $\alpha$ expression is correlated with poor prognosis in rectal cancer following chemoradiotherapy (94). Conversely, Ariga et al (95), discovered that higher expression of FAP $\alpha$ in the mesenchyme of invasive ductal carcinoma of breast cancer is associated with longer overall and disease-free survival.

\section{FAP $\alpha$ substrate cleavage}

To date, numerous endogenous substrates of FAP $\alpha$ have remained to be elucidated. In 2004, Lee et al (96) discovered and purified a proteinase from human plasma, antiplasmin-cleaving enzyme (APCE), which is capable of cleaving the Pro12-Asn13 bond of Met- $\alpha 2$-antiplasmin ( $\alpha 2$-AP) to yield Asn- $\alpha 2$-AP. Subsequently, this APCE was identified as a soluble form of FAP $\alpha$ (97). In addition to $\alpha 2-\mathrm{AP}$, gelatin and collagen, further substrates have been identified. Recently, neuropeptide Y, B-type natriuretic peptide, peptide YY, incretins, substance P, glucagon-like peptide-1 and glucose-dependent insulinotropic peptide were identified as substrates of FAP $\alpha$ (98). A study indicated that $\alpha 2$-AP was not a robust substrate of FAP $\alpha$ in vitro, but a novel substrate, Spry2 (also called Sprouty2, a member of the Sprouty family) was identified (99).

\section{Clinical applications of FAP $\alpha$ targeting}

The general and abundant expression of FAP $\alpha$ in the stroma of tumors makes it a potential target for the diagnosis and therapy of numerous carcinomas. A phase I clinical study was executed and indicated that FAP $\alpha$ was highly expressed by reactive stromal fibroblasts in $>95 \%$ of primary and metastatic tumors in patients with colorectal carcinomas (36). A phase I open-label study demonstrated that a humanized antibody (sibrotuzumab), directed against human FAP $\alpha$ expressed by advanced or metastatic FAP $\alpha$-positive cancer, may be administered safely. However, the study did not indicate sibrotuzumab efficacy for the treatment of FAP $\alpha$-positive cancer (100). In 2003, an early phase II trial of sibrotuzumab in patients with metastatic colorectal cancer revealed that progressive disease was evident in 15 out of 17 evaluable patients (101). T cells, engineered with FAP $\alpha$-reactive chimeric antigen receptors and stimulated with FAP $\alpha$ or FAP $\alpha$-expressing cell lines, degranulated and produced effector cytokines (102). However, adoptive transfer of FAP $\alpha$-reactive T cells into mice infected with various tumors, mediated weak antitumor effects (102). FAP $\alpha$-specific redirected $\mathrm{T}$ cells for the treatment of FAP $\alpha$-positive malignant pleural mesothelioma are currently subject to clinical trials (103).

\section{Conclusion}

The tumor stroma has been increasingly recognized as a vital participant in tumorigenesis, drug-resistance, angiogenesis, invasion and metastasis in numerous types of cancer. FAP $\alpha$ is highly expressed in CAFs and is important in mediating their function. Ubiquitous expression by the majority of the stroma of epithelial tumors makes FAP $\alpha$ an ideal target for cancer therapy. Since the discovery of FAP $\alpha$, it has been studied extensively. However, though a large amount of promising results were observed in vitro, clinical application of FAP $\alpha$-targeting has thus far remained ineffective. In view of the complexity of its functions, FAP $\alpha$ requires further study.

\section{Acknowledgements}

The authors would like to thank their colleagues at the Department of Hematology, The First Affiliated Hospital, Zhejiang University, Hangzhou, China. The present review was supported by the Major Research Plan of the National Natural Science Foundation of China (no. 91029740) and the National Natural Science Foundation of China (no. 81071936).

\section{References}

1. Paget $\mathrm{S}$ : The distribution of secondary growths in cancer of the breast. 1889. Cancer Metastasis Rev 8: 98-101, 1989.

2. Jones PA and SB Baylin: The fundamental role of epigenetic events in cancer. Nat Rev Genet 3: 415-428, 2002.

3. Bhowmick NA, Neilson EG and Moses HL: Stromal fibroblasts in cancer initiation and progression. Nature 432: 332-337, 2004.

4. Hertenstein B, Hambach L, Bacigalupo A, Schmitz N, McCann S, Slavin S, Gratwohl A, Ferrant A, Elmaagacli A, Schwertfeger R, et al; Chronic Leukaemia Working Party of the European Group for Blood and Marrow Transplantation: Development of leukemia in donor cells after allogeneic stem cell transplantation - a survey of the European Group for Blood and Marrow Transplantation (EBMT). Haematologica 90: 969-975, 2005.

5. Sala-Torra O, Hanna C, Loken MR, Flowers ME, Maris M, Ladne PA, Mason JR, Senitzer D, Rodriguez R, Forman SJ, et al: Evidence of donor-derived hematologic malignancies after hematopoietic stem cell transplantation. Biol Blood Marrow Transplant 12: 511-517, 2006.

6. Xiao H, Shi J, Luo Y, Tan Y, He J, Xie W, Zhang L, Wang Y, Liu L, Wu K, et al: First report of multiple CEBPA mutations contributing to donor origin of leukemia relapse after allogeneic hematopoietic stem cell transplantation. Blood 117: 5257-5260, 2011.

7. Raaijmakers MH, Mukherjee S, Guo S, Zhang S, Kobayashi T, Schoonmaker JA, Ebert BL, Al-Shahrour F, Hasserjian RP, Scadden EO, et al: Bone progenitor dysfunction induces myelodysplasia and secondary leukaemia. Nature 464: 852-857, 2010

8. Ross FM, Chiecchio L, Dagrada G, Protheroe RK, Stockley DM, Harrison CJ, Cross NC, Szubert AJ, Drayson MT and Morgan GJ; UK Myeloma Forum: The $\mathrm{t}(14 ; 20)$ is a poor prognostic factor in myeloma but is associated with long-term stable disease in monoclonal gammopathies of undetermined significance. Haematologica 95: 1221-1225, 2010.

9. Walkley CR, Olsen GH, Dworkin S, Fabb SA, Swann J, McArthur GA, Westmoreland SV, Chambon P, Scadden DT and Purton LE: A microenvironment-induced myeloproliferative syndrome caused by retinoic acid receptor gamma deficiency. Cell 129: 1097-1110, 2007. 
10. Walkley CR, Shea JM, Sims NA, Purton LE and Orkin SH: Rb regulates interactions between hematopoietic stem cells and their bone marrow microenvironment. Cell 129: 1081-1095, 2007.

11. Sounni NE and Noel A: Targeting the tumor microenvironment for cancer therapy. Clin Chem 59: 85-93, 2013.

12. Zhang J and Liu J: Tumor stroma as targets for cancer therapy. Pharmacol Ther 137: 200-215, 2013.

13. Zhang B,Li M, McDonald T, Holyoake TL, Moon RT, Campana D, Shultz L and Bhatia R: Microenvironmental protection of CML stem and progenitor cells from tyrosine kinase inhibitors through $\mathrm{N}$-cadherin and Wnt- $\beta$-catenin signaling. Blood 121: 1824-1838, 2013.

14. Konopleva MY and Jordan CT: Leukemia stem cells and microenvironment: biology and therapeutic targeting. J Clin Oncol 29: 591-599, 2011.

15. Eck SM, Côté AL, Winkelman WD and Brinckerhoff CE: CXCR4 and matrix metalloproteinase-1 are elevated in breas carcinoma-associated fibroblasts and in normal mammary fibroblasts exposed to factors secreted by breast cancer cells. Mol Cancer Res 7: 1033-1044, 2009.

16. Gao MQ, Kim BG, Kang S, Choi YP, Park H, Kang KS and Cho NH: Stromal fibroblasts from the interface zone of human breast carcinomas induce an epithelial-mesenchymal transition-like state in breast cancer cells in vitro. J Cell Sci 123 (Pt 20): 3507-3514, 2010

17. Hellevik T, Pettersen I, Berg V, Winberg JO, Moe BT, Bartnes K, Paulssen RH, Busund LT, Bremnes R, Chalmers A and Martinez-Zubiaurre I: Cancer-associated fibroblasts from human NSCLC survive ablative doses of radiation but their invasive capacity is reduced. Radiat Oncol 7: 59, 2012.

18. Berdiel-Acer M, Bohem ME, López-Doriga A, Vidal A, Salazar R, Martínez-Iniesta M, Santos C, Sanjuan X. Villanueva A and Molleví DG: Hepatic carcinoma-associated fibroblasts promote an adaptative response in colorectal cancer cells that inhibit proliferation and apoptosis: nonresistant cells die by nonapoptotic cell death. Neoplasia 13: 931-946, 2011.

19. Mueller L, Goumas FA, Himpel S, Brilloff S, Rogiers X and Broering DC: Imatinib mesylate inhibits proliferation and modulates cytokine expression of human cancer-associated stromal fibroblasts from colorectal metastases. Cancer Lett 250: 329-338, 2007.

20. Henriksson ML, Edin S, Dahlin AM, Oldenborg PA, Öberg Å Van Guelpen B, Rutegård J, Stenling R and Palmqvist R: Colorectal cancer cells activate adjacent fibroblasts resulting in FGF1/FGFR3 signaling and increased invasion. Am J Pathol 178: 1387-1394, 2011.

21. Lin ZY, Chuang YH and Chuang WL: Cancer-associated fibroblasts up-regulate CCL2, CCL26, IL6 and LOXL2 genes related to promotion of cancer progression in hepatocellular carcinoma cells. Biomed Pharmacother 66: 525-529, 2012

22. True LD, Zhang H, Ye M, Huang CY, Nelson PS, von Haller PD, Tjoelker LW, Kim JS, Qian WJ, Smith RD, et al: CD90/THY1 is overexpressed in prostate cancer-associated fibroblasts and could serve as a cancer biomarker. Mod Pathol 23: 1346-1356, 2010.

23. Mao Y, Keller ET, Garfield DH, Shen K and Wang J: Stromal cells in tumor microenvironment and breast cancer. Cancer Metastasis Rev 32: 303-315, 2013

24. Mishra PJ,Humeniuk R, Medina DJ, Medina DJ, Alexe G, Mesirov JP, Ganesan S, Glod JW and Banerjee D: Carcinoma-associated fibroblast-like differentiation of human mesenchymal stem cells. Cancer Res 68: 4331-4339, 2008.

25. Lecomte J, Masset A, Blacher S, Maertens L, Gothot A, Delgaudine $\mathrm{M}$, Bruyère $\mathrm{F}$, Carnet $\mathrm{O}$, Paupert $\mathrm{J}$, Illemann $\mathrm{M}$, et al: Bone marrow-derived myofibroblasts are the providers of pro-invasive matrix metalloproteinase 13 in primary tumor. Neoplasia 14: 943-951, 2012.

26. Fassnacht M, Lee J, Milazzo C, Boczkowski D, Su Z, Nair S and Gilboa E: Induction of CD4(+) and CD8(+) T-cell responses to the human stromal antigen, fibroblast activation protein implication for cancer immunotherapy. Clin Cancer Res 11: 5566-5571, 2005.

27. Cheng JD, Valianou M, Canutescu AA, Jaffe EK, Lee HO, Wang H, Lai JH, Bachovchin WW and Weiner LM: Abrogation of fibroblast activation protein enzymatic activity attenuates tumor growth. Mol Cancer Ther 4: 351-360, 2005.

28. Loeffler M, Kruger JA, Niethammer AG and Reisfeld RA: Targeting tumor-associated fibroblasts improves cancer chemotherapy by increasing intratumoral drug uptake. J Clin Invest 116: 1955-1962, 2006.
29. Santos AM, Jung J, Aziz N, Kissil JL and Puré E: Targeting fibroblast activation protein inhibits tumor stromagenesis and growth in mice. J Clin Invest 119: 3613-3625, 2009.

30. Kraman M, Bambrough PJ, Arnold JN, Roberts EW, Magiera L, Jones JO, Gopinathan A, Tuveson DA and Fearon DT: Suppression of antitumor immunity by stromal cells expressing fibroblast activation protein-alpha. Science 330: 827-830, 2010.

31. Rettig WJ, Chesa PG, Beresford HR, Feickert HJ, Jennings MT, Cohen J, Oettgen HF and Old LJ: Differential expression of cell surface antigens and glial fibrillary acidic protein in human astrocytoma subsets. Cancer Res 46 (12 Pt 2): 6406-6412, 1986.

32. Rettig WJ, Garin-Chesa P, Beresford HR, Oettgen HF, Melamed MR and Old LJ: Cell-surface glycoproteins of human sarcomas: differential expression in normal and malignant tissues and cultured cells. Proc Natl Acad Sci USA 85: 3110-3114, 1988.

33. Rettig WJ, Garin-Chesa P, Healey JH, Su SL, Ozer HL, Schwab M, Albino AP and Old LJ: Regulation and heteromeric structure of the fibroblast activation protein in normal and transformed cells of mesenchymal and neuroectodermal origin. Cancer Res 53: 3327-3335, 1993.

34. Rettig WJ, Su SL, Fortunato SR, Scanlan MJ, Raj BK, Garin-Chesa P, Healey JH and Old LJ: Fibroblast activation protein: purification, epitope mapping and induction by growth factors. Int J Cancer 58: 385-392, 1994.

35. Scanlan MJ, Raj BK, Calvo B, Garin-Chesa P, Sanz-Moncasi MP, Healey JH, Old LJ and Rettig WJ: Molecular cloning of fibroblast activation protein alpha, a member of the serine protease family selectively expressed in stromal fibroblasts of epithelial cancers. Proc Natl Acad Sci USA 91: 5657-5661, 1994.

36. Welt S, Divgi CR, Scott AM, Garin-Chesa P, Finn RD, Graham M, Carswell EA, Cohen A, Larson SM, Old LJ, et al: Antibody targeting in metastatic colon cancer: a phase I study of monoclonal antibody F19 against a cell-surface protein of reactive tumor stromal fibroblasts. J Clin Oncol 12: 1193-1203, 1994.

37. Niedermeyer J, Scanlan MJ, Garin-Chesa P, Daiber C, Fiebig HH, Old LJ, Rettig WJ and Schnapp A: Mouse fibroblast activation protein: molecular cloning, alternative splicing and expression in the reactive stroma of epithelial cancers. Int $\mathrm{J}$ Cancer 71 383-389, 1997.

38. Aoyama A and Chen WT: A 170-kDa membrane-bound protease is associated with the expression of invasiveness by human malignant melanoma cells. Proc Natl Acad Sci USA. 87: 8296-8300, 1990.

39. Monsky WL, Lin CY, Aoyama A, Kelly T, Akiyama SK, Mueller SC and Chen WT: A potential marker protease of invasiveness, seprase, is localized on invadopodia of human malignant melanoma cells. Cancer Res 54: 5702-5710, 1994.

40. Piñeiro-Sánchez ML, Goldstein LA, Dodt J, Howard L, Yeh Y, Tran H, Argraves WS and Chen WT: Identification of the $170-\mathrm{kDa}$ melanoma membrane-bound gelatinase (seprase) as a serine integral membrane protease. J Biol Chem 272: 7595-7601, 1997.

41. Mathew S, Scanlan MJ,Mohan Raj BK, Murty VV, Garin-Chesa P, Old LJ, Rettig WJ and Chaganti RS: The gene for fibroblast activation protein alpha (FAP), a putative cell surface-bound serine protease expressed in cancer stroma and wound healing, maps to chromosome band 2q23. Genomics 25: 335-337, 1995.

42. Kelly T: Fibroblast activation protein-alpha and dipeptidyl peptidase IV (CD26): cell-surface proteases that activate cell signaling and are potential targets for cancer therapy. Drug Resist Updat 8: 51-58, 2005.

43. Aertgeerts K, Levin I, Shi L, Snell GP, Jennings A, Prasad GS, Zhang Y, Kraus ML, Salakian S, Sridhar V, et al: Structural and kinetic analysis of the substrate specificity of human fibroblast activation protein alpha. J Biol Chem 280: 19441-19444, 2005.

44. Rosenblum JS and Kozarich JW: Prolyl peptidases: a serine protease subfamily with high potential for drug discovery. Curr Opin Chem Biol 7: 496-504, 2003.

45. Yazbeck R, Howarth GS and Abbott CA: Dipeptidyl peptidase inhibitors, an emerging drug class for inflammatory disease? Trends Pharmacol Sci 30: 600-607, 2009.

46. Sedo A and Malík R: Dipeptidyl peptidase IV-like molecules: homologous proteins or homologous activities? Biochim Biophys Acta 1550: 107-116, 2001

47. Qi SY, Riviere PJ, Trojnar J, Junien JL and Akinsanya KO: Cloning and characterization of dipeptidyl peptidase 10, a new member of an emerging subgroup of serine proteases. Biochem J 373 (Pt 1): 179-189, 2003 
48. Ghersi G,Zhao Q, Salamone M, Yeh Y,Zucker S and Chen WT: The protease complex consisting of dipeptidyl peptidase IV and seprase plays a role in the migration and invasion of human endothelial cells in collagenous matrices. Cancer Res 66: 4652-4661, 2006.

49. Park JE, Lenter MC, Zimmermann RN, Garin-Chesa P, Old LJ and Rettig WJ: Fibroblast activation protein, a dual specificity serine protease expressed in reactive human tumor stromal fibroblasts. J Biol Chem 274: 36505-36512, 1999.

50. Abbott CA, Baker E, Sutherland GR and McCaughan GW: Genomic organization, exact localization, and tissue expression of the human CD26 (dipeptidyl peptidase IV) gene. Immunogenetics 40: 331-338, 1994.

51. Abbott CA, Yu DM, Woollatt E, Sutherland GR, McCaughan GW and Gorrell MD: Cloning, expression and chromosomal localization of a novel human dipeptidyl peptidase (DPP) IV homolog, DPP8. Eur J Biochem 267: 6140-6150, 2000.

52. Yokotani N, Doi K, Wenthold RJ and Wada K: Non-conservation of a catalytic residue in a dipeptidyl aminopeptidase IV-related protein encoded by a gene on human chromosome 7. Hum Mol Genet 2: 1037-1039, 1993.

53. Zhang J, Valianou M and Cheng JD: Identification and characterization of the promoter of fibroblast activation protein. Front Biosci (Elite Ed) 2: 1154-1163, 2010.

54. Garin-Chesa P, Old LJ and Rettig WJ: Cell surface glycoprotein of reactive stromal fibroblasts as a potential antibody target in human epithelial cancers. Proc Natl Acad Sci U S A 87: 7235-7239, 1990.

55. Kelly T, Kechelava S, Rozypal TL, West KW and Korourian S: Seprase, a membrane-bound protease, is overexpressed by invasive ductal carcinoma cells of human breast cancers. Mod Pathol 11: 855-863, 1998.

56. Levy MT, McCaughan GW, Abbott CA, Park JE, Cunningham AM, Müller E, Rettig WJ and Gorrell MD: Fibroblast activation protein: a cell surface dipeptidyl peptidase and gelatinase expressed by stellate cells at the tissue remodelling interface in human cirrhosis. Hepatology 29: 1768-1778, 1999.

57. Acharya PS, Zukas A, Chandan V, Katzenstein AL and Puré E: Fibroblast activation protein: a serine protease expressed at the remodeling interface in idiopathic pulmonary fibrosis. Hum Pathol 37: 352-360, 2006.

58. Bauer S, Jendro MC, Wadle A, Kleber S, Stenner F, Dinser R, Reich A, Faccin E, Gödde S, Dinges H, et al: Fibroblast activation protein is expressed by rheumatoid myofibroblast-like synoviocytes. Arthritis Res Ther 8: R171, 2006.

59. Rovedatti L, Di Sabatino A, Knowles CH, Sengupta N, Biancheri P, Corazza GR and MacDonald TT: Fibroblast activation protein expression in Crohn's disease strictures. Inflamm Bowel Dis 17: 1251-1253, 2011.

60. Brokopp CE, Schoenauer R, Richards P, Bauer S, Lohmann C, Emmert MY, Weber B, Winnik S, Aikawa E, Graves K, et al: Fibroblast activation protein is induced by inflammation and degrades type I collagen in thin-cap fibroatheromata. Eur Heart J 32: 2713-2722, 2011.

61. Ge Y, Zhan F, Barlogie B, Epstein J, Shaughnessy J Jr and Yaccoby S: Fibroblast activation protein (FAP) is upregulated in myelomatous bone and supports myeloma cell survival. Br J Haematol 133: 83-92, 2006.

62. Bae S, Park CW, Son HK, Ju HK, Paik D, Jeon CJ, Koh GY, Kim J and Kim H: Fibroblast activation protein alpha identifies mesenchymal stromal cells from human bone marrow. Br J Haematol 142: 827-830, 2008

63. Haniffa MA, Collin MP, Buckley CD and Dazzi F: Mesenchymal stem cells: the fibroblasts' new clothes? Haematologica 94 258-263, 2009.

64. Shi M, Yu DH, Chen Y, Zhao CY, Zhang J, Liu QH, Ni CR and Zhu MH: Expression of fibroblast activation protein in human pancreatic adenocarcinoma and its clinicopathological significance. World J Gastroenterol 18: 840-846, 2012.

65. Iwasa S, Okada K, Chen WT, Jin X, Yamane T, Ooi A and Mitsumata M: 'Increased expression of seprase, a membrane-type serine protease, is associated with lymph node metastasis in human colorectal cancer'. Cancer Lett 227: 229-236, 2005.

66. Mori Y, Kono K, Matsumoto Y, Fujii H, Yamane T, Mitsumata M and Chen WT: The expression of a type II transmembrane serine protease (Seprase) in human gastric carcinoma. Oncology 67 411-419, 2004

67. Jin X, Iwasa S, Okada K, Mitsumata M and Ooi A: Expression patterns of seprase, a membrane serine protease, in cervical carcinoma and cervical intraepithelial neoplasm. Anticancer Res 23: 3195-3198, 2003
68. Mentlein R, Hattermann K, Hemion C, Jungbluth AA and Held-Feindt J: Expression and role of the cell surface protease seprase/fibroblast activation protein- $\alpha$ (FAP- $\alpha)$ in astroglial tumors. Biol Chem 392: 199-207, 2011.

69. Wäster P, Rosdahl I, Gilmore BF and Seifert O: Ultraviolet exposure of melanoma cells induces fibroblast activation protein- $\alpha$ in fibroblasts: Implications for melanoma invasion. Int J Oncol 39: 193-202, 2011.

70. Cheng JD, Dunbrack RL Jr, Valianou M, Rogatko A, Alpaugh RK and Weiner LM: Promotion of tumor growth by murine fibroblast activation protein, a serine protease, in an animal model. Cancer Res 62: 4767-4772, 2002.

71. Huang Y, Wang S and Kelly T: Seprase promotes rapid tumor growth and increased microvessel density in a mouse model of human breast cancer. Cancer Res 64: 2712-2716, 2004.

72. GoodmanJD,RozypalTLandKellyT:Seprase,amembrane-bound protease, alleviates the serum growth requirement of human breast cancer cells. Clin Exp Metastasis 20: 459-470, 2003.

73. Lai D, Ma L and Wang F: Fibroblast activation protein regulates tumor-associated fibroblasts and epithelial ovarian cancer cells. Int J Oncol 41: 541-550, 2012

74. Fischer E, Chaitanya K, Wüest T, Wadle A, Scott AM, van den Broek M, Schibli R, Bauer S and Renner C: Radioimmunotherapy of fibroblast activation protein positive tumors by rapidly internalizing antibodies. Clin Cancer Res 18: 6208-6218, 2012.

75. Pennisi A, Li X, Ling W, Khan S, Gaddy D, Suva LJ, Barlogie B, Shaughnessy JD, Aziz N and Yaccoby S: Inhibitor of DASH proteases affects expression of adhesion molecules in osteoclasts and reduces myeloma growth and bone disease. $\mathrm{Br} \mathrm{J}$ Haematol 145: 775-787, 2009.

76. Adams S, Miller GT, Jesson MI, Watanabe T, Jones B and Wallner BP: PT-100, a small molecule dipeptidyl peptidase inhibitor, has potent antitumor effects and augments antibody-mediated cytotoxicity via a novel immune mechanism. Cancer Res 64: 5471-5480, 2004.

77. van der Bruggen $\mathrm{P}$, Traversari $\mathrm{C}$, Chomez $\mathrm{P}$, Lurquin $\mathrm{C}$, De Plaen E, Van den Eynde B, Knuth A and Boon T: A gene encoding an antigen recognized by cytolytic $\mathrm{T}$ lymphocytes on a human melanoma. Science 254: 1643-1647, 1991

78. Liao D, Luo Y, Markowitz D, Xiang R and Reisfeld RA: Cancer associated fibroblasts promote tumor growth and metastasis by modulating the tumor immune microenvironment in a 4T1 murine breast cancer model. PLoS One 4: e7965, 2009.

79. Huber MA, Kraut N, Park JE, Schubert RD, Rettig WJ, Peter RU and Garin-Chesa P: Fibroblast activation protein: differential expression and serine protease activity in reactive stromal fibroblasts of melanocytic skin tumors. J Invest Dermatol 120: $182-188,2003$

80. Tsujimoto H, Nishizuka S, Redpath JL and Stanbridge EJ: Differential gene expression in tumorigenic and nontumorigenic HeLa x normal human fibroblast hybrid cells. Mol Carcinog 26: 298-304, 1999.

81. Brown DD, Wang Z, Furlow JD, Kanamori A, Schwartzman RA, Remo BF and Pinder A: The thyroid hormone-induced tail resorption program during Xenopus laevis metamorphosis. Proc Natl Acad Sci USA 93: 1924-1929, 1996.

82. Ramirez-Montagut T, Blachere NE, Sviderskaya EV, Bennett DC, Rettig WJ, Garin-Chesa P and Houghton AN: FAPalpha, a surface peptidase expressed during wound healing, is a tumor suppressor. Oncogene 23: 5435-5446, 2004.

83. Roberts EW, Deonarine A, Jones JO, Denton AE, Feig C, Lyons SK, Espeli M, Kraman M, McKenna B, Wells RJ, et al: Depletion of stromal cells expressing fibroblast activation protein- $\alpha$ from skeletal muscle and bone marrow results in cachexia and anemia. J Exp Med 210: 1137-1151, 2013.

84. Niedermeyer J, Kriz M, Hilberg F, Garin-Chesa P, Bamberger U, Lenter MC, Park J, Viertel B, Püschner H, Mauz M, Rettig WJ and Schnapp A: Targeted disruption of mouse fibroblast activation protein. Mol Cell Biol 20: 1089-1094, 2000.

85. Jacob M, Chang L and Puré E: Fibroblast activation protein in remodeling tissues. Curr Mol Med 12: 1220-1243, 2012.

86. Ghersi G, Dong H, Goldstein LA, Yeh Y, Hakkinen L, Larjava HS and Chen WT: Regulation of fibroblast migration on collagenous matrix by a cell surface peptidase complex. J Biol Chem 277: 29231-29241, 2002.

87. Chen WT and Kelly T: Seprase complexes in cellular invasiveness. Cancer Metastasis Rev 22: 259-269, 2003.

88. O'Brien P and O'Connor BF: Seprase: an overview of an important matrix serine protease. Biochim Biophys Acta 1784: 1130-1145, 2008. 
89.Lee HO, Mullins SR, Franco-Barraza J, Valianou M, Cukierman E and Cheng JD: FAP-overexpressing fibroblasts produce an extracellular matrix that enhances invasive velocity and directionality of pancreatic cancer cells. BMC Cancer 11: $245,2011$.

90. Wang XM, Yu DM, McCaughan GW and Gorrell MD: Fibroblast activation protein increases apoptosis, cell adhesion, and migration by the LX-2 human stellate cell line. Hepatology 42: 935-945, 2005.

91. Wikberg ML, Edin S, Lundberg IV, Van Guelpen B, Dahlin AM, Rutegård J, Stenling R, Oberg A and Palmqvist R: High intratumoral expression of fibroblast activation protein (FAP) in colon cancer is associated with poorer patient prognosis. Tumour Biol 34: 1013-1020, 2013.

92. Cohen SJ, Alpaugh RK, Palazzo I, Meropol NJ, Rogatko A, Xu Z, Hoffman JP, Weiner LM and Cheng JD: Fibroblast activation protein and its relationship to clinical outcome in pancreatic adenocarcinoma. Pancreas 37: 154-158, 2008.

93. Henry LR, Lee HO, Lee JS, Klein-Szanto A, Watts P, Ross EA, Chen WT and Cheng JD: Clinical implications of fibroblast activation protein in patients with colon cancer. Clin Cancer Res 13: 1736-1741, 2007.

94. Saigusa S, Toiyama Y, Tanaka K, Yokoe T, Okugawa Y, Fujikawa H, Matsusita K, Kawamura M, Inoue Y, Miki C and Kusunoki M: Cancer-associated fibroblasts correlate with poor prognosis in rectal cancer after chemoradiotherapy. Int $\mathrm{J}$ Oncol 38: 655-663, 2011.

95. Ariga N, Sato E, Ohuchi N, Nagura H and Ohtani H: Stromal expression of fibroblast activation protein/seprase, a cell membrane serine proteinase and gelatinase, is associated with longer survival in patients with invasive ductal carcinoma of breast. Int J Cancer 95: 67-72, 2001.
96. Lee KN, Jackson KW, Christiansen VJ, Chung KH and McKee PA A novel plasma proteinase potentiates alpha2-antiplasmin inhibition of fibrin digestion. Blood 103: 3783-3788, 2004.

97. Lee KN, Jackson KW, Christiansen VJ, Lee CS, Chun JG and McKee PA: Antiplasmin-cleaving enzyme is a soluble form of fibroblast activation protein. Blood 107: 1397-1404, 2006

98. Keane FM, Nadvi NA, Yao TW and Gorrell MD: Neuropeptide Y, B-type natriuretic peptide, substance $\mathrm{P}$ and peptide $\mathrm{YY}$ are novel substrates of fibroblast activation protein- $\alpha$. FEBS J 278: 1316-1332, 2011.

99. Huang CH, Suen CS, Lin CT, Chien CH, Lee HY, Chung KM, Tsai TY, Jiaang WT, Hwang MJ and Chen X: Cleavage-site specificity of prolyl endopeptidase FAP investigated with a full-length protein substrate. J Biochem 149: 685-692, 2011.

100. Scott AM, Wiseman G, Welt S, Adjei A, Lee FT, Hopkins W Divgi CR, Hanson LH, Mitchell P, Gansen DN, et al: A Phase I dose-escalation study of sibrotuzumab in patients with advanced or metastatic fibroblast activation protein-positive cancer. Clin Cancer Res 9: 1639-1647, 2003.

101. Hofheinz RD, al-Batran SE, Hartmann F, Hartung G, Jäger D Renner C, Tanswell P, Kunz U, Amelsberg A, Kuthan H and Stehle G: Stromal antigen targeting by a humanised monoclonal antibody: an early phase II trial of sibrotuzumab in patients with metastatic colorectal cancer. Onkologie 26: 44-48, 2003.

102. Tran E, Chinnasamy D, Yu Z, Morgan RA, Lee CC, Restifo NP and Rosenberg SA: Immune targeting of fibroblast activation protein triggers recognition of multipotent bone marrow stromal cells and cachexia. J Exp Med 210: 1125-1135, 2013.

103. Petrausch U, Schuberth PC, Hagedorn C, Soltermann A, Tomaszek S, Stahel R, Weder W and Renner C: Re-directed T cells for the treatment of fibroblast activation protein (FAP)-positive malignant pleural mesothelioma (FAPME-1). BMC Cancer 12: 615, 2012. 